INSIGHTS INTO REGIONAL DEVELOPMENT

ISSN 2669-0195 (online) http://jssidoi.org/IRD/

2021 Volume 3 Number 4 (December)

http://doi.org/10.9770/IRD.2021.3.4(7)
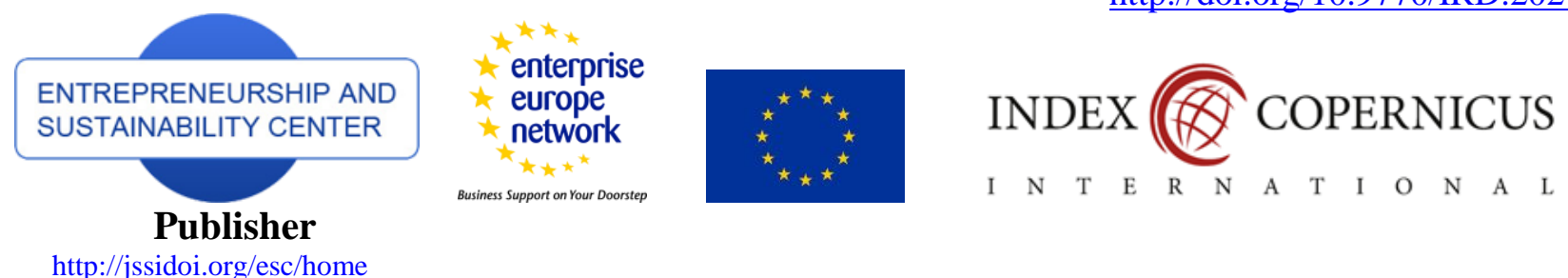

$\begin{array}{lllllllllllll}\text { I } & \mathrm{N} & \mathrm{T} & \mathrm{E} & \mathrm{R} & \mathrm{N} & \mathrm{A} & \mathrm{T} & \mathrm{I} & \mathrm{O} & \mathrm{N} & \mathrm{A} & \mathrm{L}\end{array}$

http://jssidoi.org/esc/home

\title{
RESEARCH ON THE REFLECTION OF CULTURAL DIMENSIONS IN INTERNATIONAL BUSINESS *
}

\author{
Edita Leonavičienė ${ }^{1}$, Aurelija Burinskienė ${ }^{2}$ \\ Vilnius Gediminas Technical University (VILNIUSTECH), Sauletekio al. 11, LT-10223 Vilnius, Lithuania \\ E-mails: ${ }^{1}$ edita.leonaviciene@vilniustech.lt ; $^{2}$ aurelija.burinskiene@vilniustech.lt
}

Received 11 November 2021; accepted 20 December 2021; published 30 December 2021

\begin{abstract}
The objective of this research is to reveal the reflection of cultural dimensions in international business. The management of an international business is complex and varies according to culturally determined values. To achieve success in international business, it is necessary to understand how cultural differences across and within countries affect it. Authors took under revision the international companies listed under the Nasdaq database (2021) and researched interlinks in the North-West region of Europe. The authors delivered the research in two stages. In the first stage, the authors constructed a matrix of cultural dimensions. Then formed the equation at the second step by using the Generalized Moments Method, which eliminates inaccurate assumptions. The authors used panel data analysis and constructed equations. The theoretical research results highlight the cultural dimensions identified in the 31 studies in the priority of attention. The authors' research proves that three main cultural dimensions affect the revenue of the international business. We came to the insight that the impact of culture in doing business globally is growing rapidly.
\end{abstract}

Keywords: international business; cultural differences; dimensions

Reference to this paper should be made as follows: Leonavičienè E., Burinskienè A. 2021 Research on the reflection of cultural dimensions in international business. Insights into Regional Development, 3(4), 101-114. http://doi.org/10.9770/IRD.2021.3.4(7)

JEL Classifications: M14, F2, F23

\section{Introduction}

The cultural environment is important for international business. Many researches were delivered in the area. However, the authors do not combine cultural elements with international business revenue indicators.

In international business literature, authors stress that companies operating in international markets face more competition and must therefore be able to decide quickly (Centre, 2017). The literature states that these companies are most likely willing to learn rapidly and are proactively and dynamically changing. It is proposed to combine the experience taken from the mother company and consider that the success of companies can be

\footnotetext{
* The research was partly supported by The program of internationalization of scientific research of KUL no. W.106.I.2019

(Paths of cooperation - support for entities implementing international cooperation), funded by European Social Fund
} 
achieved by actively finding new markets, responding to ongoing changes, increasing the value of goods and the volume of trade. Some argue international competition promotes greater efficiency (Ferreira et al., 2007; Sitharam \& Hoque, 2016)

The authors revised scientific literature published on the topic Oxford University Press, Cambridge University Press, Harvard University Press, Springer, M.E. Sharpe, Routledge, other publishers and identified that they rarely discuss the thematic of cultural differences under the literature on international business. The analysis presented under Table 1 shows that only 0.66 percent of the above publications give the investigations in the research area.

Table 1. Literature revision (created by authors)

\begin{tabular}{ccc}
\hline Year & Literature On International Business & $\begin{array}{c}\text { Thematic of Cultural Differences } \\
\text { Under the Literature on } \\
\text { International Business, }\end{array}$ \\
\hline $1994-1998$ & 81400 & 473 \\
\hline $1999-2003$ & 122000 & 1100 \\
\hline $2004-2008$ & 118000 & 973 \\
\hline $2009-2013$ & 235000 & 1700 \\
\hline $2014-2018$ & 286000 & 1760 \\
\hline $2019-2021$ & 365000 & 1950 \\
\hline Total & 1207400 & 7956 \\
\hline$\%$ & $\mathbf{1 0 0 \%}$ & $\mathbf{0 . 6 6 \%}$ \\
\hline
\end{tabular}

Source: constructed by authors, according to publications published Oxford University Press, Cambridge University Press, Harvard University Press, Springer, M.E. Sharpe, Routledge, and other publishers

\section{Literature review}

The literature review combines two dimensions: cultural differences and their replication in the management of an international business.

\section{Cultural differences}

In the literature, you can find studies that compare the applicability of cultural frameworks to determine which cultural dimension measure is appropriate $(\mathrm{Ng} \& \mathrm{Lim}, 2019$; Witte et al., 2020) In the scientific literature, according the authors, the primary authors examining the cultural dimension in international business are G. Hofstede, E.T. Hall, S.H. Schwartz, and F. Trompenaars.

The authors present the components of how they define culture and impact on communication and business. Despite the development of cultures, these methods provide a comprehensive and long-term understanding of the critical factors that shape culture, affecting every aspect of business worldwide.

S. H. Schwartz's (Masuda et al., 2020) theory refers to three bipolar dimensions of culture:

\section{Insertion vs autonomy}

In the cultures of autonomy, people are autonomous, restricted entities. This led them to develop and express their wishes, feelings, ideas, and abilities. S. H. Schwartz divided autonomy into two types: 1. Intellectual autonomyencourages individuals to pursue their ideas and intellectual directions independently. 2. Emotional autonomy that encourages people to pursue positive emotional experiences. Embedded cultures emphasize the maintenance of the status quo and acts of restraint that can disrupt group solidarity or traditional order. 


\section{Hierarchy vs egalitarianism}

Cultural egalitarianism seeks to encourage people to recognize each other on moral levels who have fundamental interests as human beings. They based the alternative polar hierarchy of culture on hierarchical systems of assigned roles to ensure responsible, productive behavior.

3. Mastery vs harmony

The harmony of the cultural response is a change that is taking place in the social and natural world. It linked this to environmental protection and world peace.

Schwartz's system of cultural dimensions was constructed by revising data in 75 countries since 1994 .

E.T. Hall (Lanigan, 1978) singled out three major categories that analyses and interpret the differences in intercultural relationships and interactions:

1. High vs low-context cultures

In a culture of high context, many contextual elements help people understand the rules (body language, a person's status). That is a direct contrast to low-context cultures, that more clarification is needed.

2. Space

Space shows the perception of physical distance between people. That shows how people behave when they are in one space, close to each other.

3. Attitude to time: polychronic and monochronic cultures.

In polychronic cultures, polychronic means "many times", people can do several things simultaneously. In monochronic cultures or "disposable" cultures, people perform one task at a time.

F. Trompenaars (1993) presents a seven-dimensional model of national culture differences, which he argues applies to the conduct of international business. It offers the following dimensions:

1. Universalism against Specificity

Universalism is the search for broad and standard rules. Specificity is about finding exceptions.

2. Analysis vs Integration

The analysis breaks down to find detailed information. The integration combines things to create an overall picture. He assumed that if someone has ahead in the weeds, he would miss the fundamental understanding.

3. Individualism against Communism

Individualism is about individual rights. Communism is about the rights of a group or society.

4. Internal directed vs external redirect

Internal perception is a person's opinion, and external perception is what information is available in society.

5. Synchronization of time compared to Time series

When synchronizing events and time, time coordination procedures are established in parallel. In a time, series, events are predicted in a separate sequence as separate elements.

6. Status achieved compared to the assigned status

The status achieved is the acquisition of the state through performance. The status assigned is about acquiring the status by others.

7. Hierarchy vs Equality

The hierarchy is about people who are superior to others. They assume that the order happens when few are blamed, while others obey through the scalar chain of command. Equality is for all people with the same status (Manrai \& Manrai, 2010). 
INSIGHTS INTO REGIONAL DEVELOPMENT

ISSN 2669-0195 (online) http://jssidoi.org/jesi/

2021 Volume 3 Number 4 (December)

http://doi.org/10.9770/IRD.2021.3.4(7)

Table 2. Table authors and their proposed original concepts of cultural dimensions

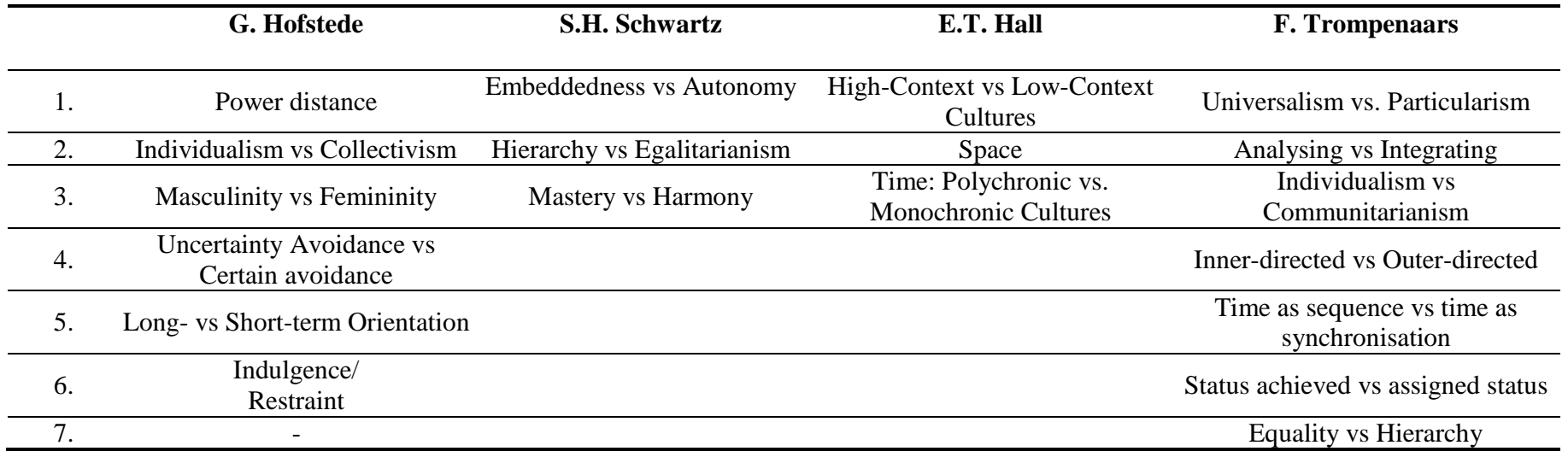

Source: constructed by authors

More external factors make up culture. These include manners, mindsets, values, rituals, religious beliefs, art, customs, ceremonies, various institutions, laws, language, beliefs, individual behavior. However, these identified factors are still less structured and do not make up a comparative system.

The combination of intercultural analysis and business is a new and developing field; it is not a static understanding but a changing world. While new ideas are constantly being presented, G. Hofstede remains a leading thinker on how we see cultures. The Hofstede cultural dimension system, which has been in place since 1980, covers 111 countries, although detailed data are provided for 65 countries with all six aspects. G. Hofstede is named the pioneer of modern intercultural science theory, comparing nations using statistical analysis of two databases. Thus, the study was based on the cultural aspects proposed by this author.

G. Hofstede has developed a model where global cultural differences will be divided into five dimensions. These dimensions include:

1. Power distance: inequality between people that the population of the country considers normal.

2. Individualism or collectivism: the degree to which the country's inhabitants wish to behave as individuals or members of a group.

3. Masculinity or femininity: the degree to which values such as strength, productivity, success and competitiveness are used in decision-making.

4. Avoiding uncertainty: the preference of the citizens of the country for a structured, overly unstructured situation, the rigor of procedures, or the willingness to risk a collapse.

5. Orientation to the long-term or short-term perspective: to what extent decisions are based on long-term orientation versus short-term orientation? They are made on time and based on the past and assessing past and future conditions (Agodzo, 2014).

Later on, M. Minkov (Hofstede, Hofstede, Minkov, 2010) proposed the sixth one dimension - indulgence. Indulgence stands for the society is an acceptable, free desire for people to enjoy life and to satisfy their desires. Restriction - when strict social norms in society control the satisfaction of society's needs.

The core of G. Hofstede's advantage over alternative models is quantifiable, understood, available for intercountry comparisons, replicable, and accepted cultural taxonomy, which helps in international business research. Can measure cultural characteristics that are facilitating the inclusion of culture in international business.

The authors revised the literature and identified which cultural dimensions take the highest and the lowest attention in the studies by revising 31 authors. Among studies, the individualism (collectivism) dimension gets the greater attention, and the indulgence dimension gets the lowest attention (see Table 3). 
INSIGHTS INTO REGIONAL DEVELOPMENT

ISSN 2669-0195 (online) http://jssidoi.org/jesi/ 2021 Volume 3 Number 4 (December) http://doi.org/10.9770/IRD.2021.3.4(7)

Table 3. Dimensions of cultural dimensions (created by authors)

\begin{tabular}{|c|c|c|c|c|c|c|}
\hline $\begin{array}{l}\text { Dimensions of cultural } \\
\text { difference }\end{array}$ & $\begin{array}{l}\text { Power } \\
\text { distance }\end{array}$ & $\begin{array}{l}\text { Individualism/ } \\
\text { Collectivism }\end{array}$ & $\begin{array}{l}\text { Masculinity/ } \\
\text { Femininity }\end{array}$ & $\begin{array}{l}\text { Uncertainty } \\
\text { avoidance } \\
\text { Uncertainty } \\
\text { tolerance }\end{array}$ & $\begin{array}{l}\text { Long term } \\
\text { orientation/ } \\
\text { Short-Term } \\
\text { Orientation }\end{array}$ & $\begin{array}{c}\text { Indulgence/ } \\
\text { Restraint }\end{array}$ \\
\hline (Xu \& Hao, 2021) & + & + & + & + & + & \\
\hline (Gonzalez, 2021) & + & + & + & + & + & + \\
\hline (Vilaplana et al., 2019) & + & + & + & + & + & + \\
\hline (G. Hofstede, 1980) & + & + & + & + & & \\
\hline (G. Hofstede, 2011) & + & + & + & + & + & + \\
\hline $\begin{array}{l}\text { (Ladhari \& Skandrani, } \\
\text { 2014) }\end{array}$ & + & + & & & & \\
\hline $\begin{array}{l}\text { (Caputo, Andrea; Ayoko, } \\
\text { Oluremi B.; Amoo, Nii; } \\
\text { Menke, 2019) }\end{array}$ & + & & & & & \\
\hline (Wang et al., 2021) & + & & & & & \\
\hline (M. Liu, 2019) & + & & & & & \\
\hline (M. Liu et al., 2019) & + & & & & & \\
\hline Waistell, 2011 & & + & & & & \\
\hline Ogihara, 2018 & & + & & & & \\
\hline (Lee \& Herold, 2016) & + & + & + & + & + & \\
\hline $\begin{array}{l}\text { (Safiah, Omar, } \\
\text { Syukurriah, Idrus, 2011) }\end{array}$ & & + & & & & \\
\hline (Minh, 2015) & & + & & & & \\
\hline (Masuda et al., 2020) & & + & & + & & \\
\hline$($ Agodzo, 2014$)$ & + & + & + & + & + & + \\
\hline $\begin{array}{l}\text { (Daňková \& Droppa, } \\
\text { 2015) }\end{array}$ & + & + & + & + & + & \\
\hline (Ralston et al., 2014) & & + & & & & \\
\hline (Mockaitis et al., 2012) & & + & & & & \\
\hline (Fischer et al., 2010) & + & + & + & + & & \\
\hline (Fengfan, 2015) & + & + & + & + & + & + \\
\hline $\begin{array}{l}\text { (G. J. Hofstede et al., } \\
\text { 2008b) }\end{array}$ & & & & + & & \\
\hline $\begin{array}{l}\text { (G. J. Hofstede et al., } \\
\text { 2008a) }\end{array}$ & & & & & + & \\
\hline (Mockaitis et al., 2012) & & + & & & & \\
\hline (Fan et al., 2017) & + & + & + & + & + & \\
\hline (Merkin, 2004) & & & & & + & \\
\hline (Guo et al., 2018) & & & & & + & + \\
\hline $\begin{array}{l}\text { (G. J. Hofstede et al., } \\
\text { 2019) }\end{array}$ & + & & & & + & \\
\hline (Warter et al., 2015) & + & + & + & + & + & + \\
\hline $\begin{array}{l}\text { (P. M. das N. Ferreira, } \\
\text { 2017) }\end{array}$ & + & + & + & + & + & + \\
\hline Number of studies & 19 & 22 & 13 & 15 & 15 & 8 \\
\hline
\end{tabular}

Source: constructed by authors

A more detailed description of cultural dimensions is presented in Appendix A. These cultural dimensions follow assumptions, such as one-to-one relationship between culture and country, get index score that is created for each of dimension, which was indicated according to the authors created empirical research. 


\section{INSIGHTS INTO REGIONAL DEVELOPMENT}

ISSN 2669-0195 (online) http://jssidoi.org/jesi/

2021 Volume 3 Number 4 (December)

http://doi.org/10.9770/IRD.2021.3.4(7)

\section{Management of international business}

All economic activities carried out in cross-border transactions belong to international or foreign business. This includes all commercial activities, such as revenue, investments, logistics, etc., involving two or more parties.

A company doing international business we call the international or multinational company. These companies have a large customer base from different countries and their resources do not depend on one country. In addition, international business is investing and expanding its trade in other countries.

But there are shortcomings that hinder access to the international market, such as tariffs and quotas, political, social, cultural, economic and other factors affecting international business.

Several practices are necessary for a business to operate internationally:

1. Adaptation of global business models to the local market

Businesses can suffer setbacks and high costs without knowing the local culture and its impact on consumer demand and decision-making. Different specific changes need to be made to maintain the business. To deliver the target message in the local culture, presenting offers and different marketing strategies. The main point of businesses to exist is to pay attention to the customers' needs (Głodowska et al., 2016).

2. Knowledge of local business management

The local culture affects everything from employee management to business pace, negotiation management, and risk management. Thus, understanding local business practices is essential to international business success (Ferreira, 2017; Gujrati, 2017).

3. Implementation of different management strategies in an international company.

Poor leadership strategies can lead to losses and failures. Diversity in the workplace is a powerful tool that can be a significant attraction for high-quality global talent. A multicultural environment promotes new perspectives and approaches to problem-solving or achieving common goals (Decker, 2019; Lin, 2007).

4. Selection of human resources adapted to local culture

Globalization is crucial for the company's expansion. They must adapt personnel policies and practices to benefit their foreign employees and subsidiaries.

5. Acknowledge regional and subcultural differences

Adhering to the same behavior patterns or accepting the dominant culture's values may be unacceptable in society. Socio-economic status, original language, consumption habits and values are cultivations of differences encountered in society or a foreign country.

6. Adaptation of cultural voice from the host country

Knowledge of local dialect and communication style helps marketers reach the target audience of international business faster.

Cultural awareness helps break down cultural barriers, build cultural bridges, and appreciate those differences (Yehia, 2018). The results in more cultural connection and less cultural conflict. When encountering new languages and cultures, companies make comparisons and realize that their behaviors, values, and beliefs are not the general norm found elsewhere in the world. It helps to create a homogenous and inclusive work environment. That fosters creativity and innovation while boosting productivity and profitability (Centre, 2017; Liu \& Liu, 2011).

Context and culture are critical factors in doing business internationally. Companies create a diverse corporate and personal culture by understanding the differences in ethics, beliefs, values, and rules of different countries and developing cultural awareness.

Below the authors present the links between cultural differences and multinational enterprises (see Table 4). 
INSIGHTS INTO REGIONAL DEVELOPMENT

ISSN 2669-0195 (online) http://jssidoi.org/jesi/

2021 Volume 3 Number 4 (December)

http://doi.org/10.9770/IRD.2021.3.4(7)

Table 4. Relationship between cultural differences and multinational enterprises drawn in the scientific literature (source: compiled by authors).

\begin{tabular}{|c|c|c|c|}
\hline Relations & Country & Features & Cultural differences \\
\hline $\begin{array}{l}\text { Relationship } \\
\text { between cultural } \\
\text { distance and } \\
\text { input mode by } \\
\text { Western } \\
\text { European } \\
\text { Multinational } \\
\text { Enterprises into } \\
\text { Eastern Asia } \\
\text { (M. Liu et al., } \\
\text { 2019) }\end{array}$ & $\begin{array}{c}\text { Western } \\
\text { Europe } \\
\text { Easter Asia }\end{array}$ & $\begin{array}{l}\text { The cultural distance } \\
\text { and. sub-actors: } \\
\text { (1) distance of power, } \\
\text { (2) avoidance of uncertainty, } \\
\text { (3) collectivism of individualism, } \\
\text { (4) masculinity, } \\
\text { (5) femininity. }\end{array}$ & $\begin{array}{l}\text { Because of the distance between the home } \\
\text { country where the parent company is } \\
\text { located and the host country where the } \\
\text { establishments of the undertakings are } \\
\text { located, international failures happened } \\
\text { A business manager can choose a local } \\
\text { business partner who understands cultural } \\
\text { preferences, establishing local supply } \\
\text { chains and business rules to increase } \\
\text { operational success in the country. }\end{array}$ \\
\hline
\end{tabular}

Source: constructed by authors

When different organizations merge into one, the operation's success is not solely on maximizing market share, cost savings, and efficiencies. With international companies, the merging process brings together employees and staff from different cultures who may have very different expectations of working together.

The smooth integration of both companies depends on whether the organizations consider issues relating to national culture through cultural awareness training programs. Cross-cultural training is an integral step to ensuring international organizations harness the benefits of doing business in an intercultural context.

\section{Materials and Methods}

The cultural environment is essential for international business. The authors used the Culture compass of Hofstede (G. Hofstede, 2021) analyses considerable differences between all cultures of international business countries. Such presents thinking patterns that are reflected in the meaning that employees touch in the organization. The cultural differences of one country are more significant than the differences between the cultures of all countries. We can still use those country scores based on the laws of large numbers, and most of us heavily depend on social control. Of course, statements are generalizations, and they should be relative. The scores used for the sixth (Hofstede, Hofstede, Minkov, 2010) measure on Minkov's research.

The research is multilayer. In the first stage, authors focus on which cultural dimensions impact revenue and in the second stage, they analyze the relationships among cultural dimensions.

For the case study, the authors selected the database of Nasdaq (Nasdaq.com, 2021) and revised all listed international companies. By following the company's country, the authors identified values of cultural dimensions (as specified in Figure 1). 
INSIGHTS INTO REGIONAL DEVELOPMENT

ISSN 2669-0195 (online) http://jssidoi.org/jesi/

2021 Volume 3 Number 4 (December)

http://doi.org/10.9770/IRD.2021.3.4(7)

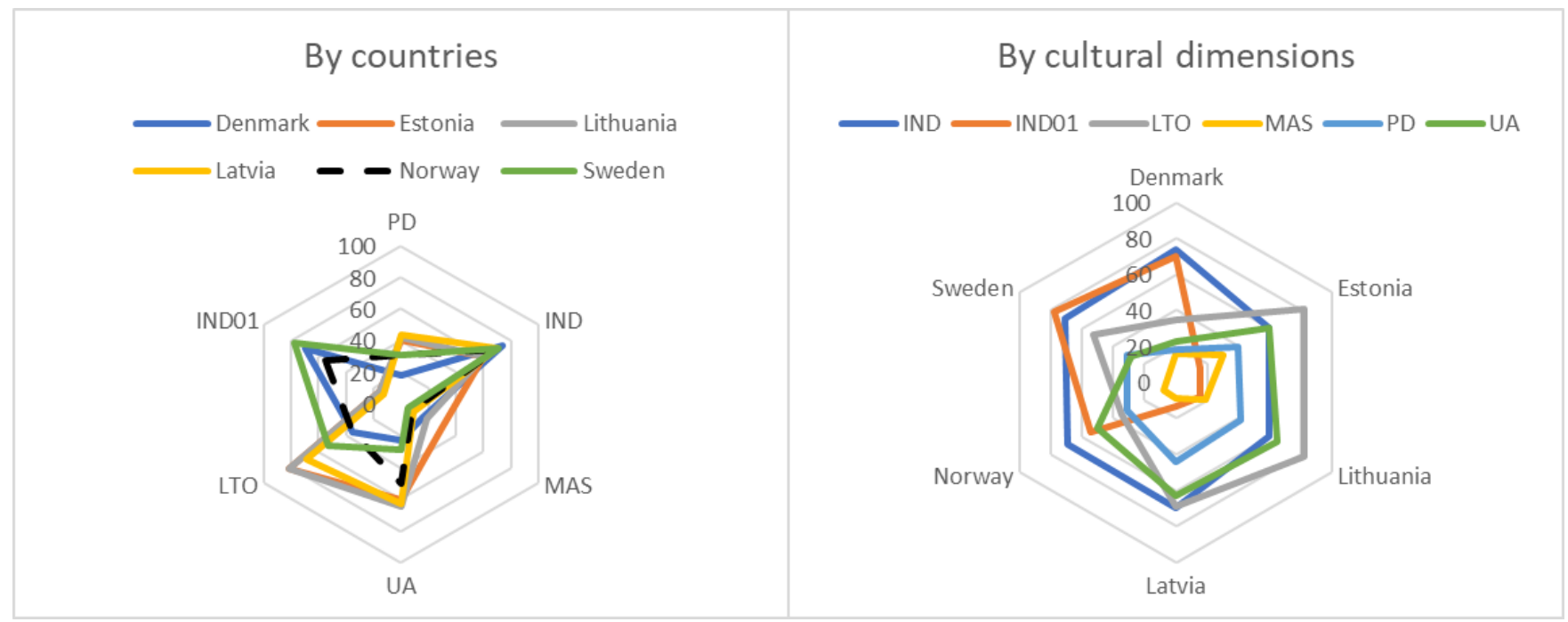

Figure 1. The profile of empiric research countries.

Where PD - Power distance, IND - Individualism, MAS - Masculinity, UA - Uncertainty avoidance, LTO Long-Term Orientation, IND01 - Indulgence.

\section{Results}

The investigations are provided on several layers: they provided the review of cultural differences on international business revenue in the first layer. The construction of the equation by following panel generalized moments method (GMM) is provided under the second layer.

\section{Impact of cultural differences on international business revenue}

The results of empirical research show such interlinks (see Table 5).

Table 5. Empirical research results: the relationship between cultural differences and company revenue

\begin{tabular}{|c|c|c|c|c|c|c|c|c|c|}
\hline Variables & & LOG(PARDAVIMAI) & LOG(IMONES_PD) & LOG(IMONES_IND) & LOG(IMONES_MAS) & VADOVAS_M_F & LOG(IMONES_UA) & LOG(IMONES_LTO) & LOG(IMONES_IND01) \\
\hline \multirow[t]{2}{*}{ LOG(PARDAVIMAI) } & Correlation coef. & 1 & $-0,2818$ & $-0,1461$ & 0,1360 & 0,1214 & $-0,2856$ & $-0,0310$ & 0,2827 \\
\hline & Probability & ---- & 0 & 0,001 & 0,002 & 0,005 & 0,000 & 0,477 & 0,000 \\
\hline \multirow[t]{2}{*}{ LOG(IMONES_PD) } & Correlation coef. & & 1 & $-0,2801$ & 0,0950 & $-0,0411$ & 0,9010 & 0,7401 & $-0,8722$ \\
\hline & Probability & & ----- & 0 & 0,029 & 0,346 & 0 & 0 & 0 \\
\hline \multirow[t]{2}{*}{ LOG(IMONES_IND) } & Correlation coef. & & & 1 & $-0,8796$ & 0,0957 & $-0,4610$ & $-0,7324$ & 0,3097 \\
\hline & Probability & & & ---- & 0 & 0,028 & 0 & 0 & 0 \\
\hline \multirow[t]{2}{*}{ LOG(IMONES_MAS) } & Correlation coef. & & & & 1 & $-0,0323$ & 0,3252 & 0,6306 & $-0,3226$ \\
\hline & Probability & & & & ----- & 0,458 & 0 & 0 & 0 \\
\hline \multirow[t]{2}{*}{ VADOVAS_M_F } & Correlation coef. & & & & & 1 & $-0,0616$ & $-0,0688$ & 0,0256 \\
\hline & Probability & & & & & $-\cdots$ & 0,157 & 0,114 & 0,556 \\
\hline \multirow[t]{2}{*}{ LOG(IMONES_UA) } & Correlation coef. & & & & & & 1 & 0,7070 & $-0,8886$ \\
\hline & Probability & & & & & & ---- & 0 & 0 \\
\hline LOG(IMONES_LTO) & $\begin{array}{l}\text { Correlation coef. } \\
\text { Probability }\end{array}$ & & & & & & & $\begin{array}{r}1 \\
---\end{array}$ & $\begin{array}{r}-0,7714 \\
0\end{array}$ \\
\hline LOG(IMONES_IND01) & $\begin{array}{l}\text { Correlation coef. } \\
\text { Probability }\end{array}$ & & & & & & & & $\begin{array}{r}1 \\
---- \\
\end{array}$ \\
\hline
\end{tabular}

Where: IMONES - Company', PARDAVIMAI - Revenue, VADOVAS - Manager, M - Male, F - Female, LOG - logarithmic value. 
According to Table 5, power distance has a negative relationship with company revenue. Individualism has a weak negative relationship, masculinity - weak positive relationship. Uncertainty avoidance-negative relationship, long-term orientation - weak negative relationship, which is close to zero and has a high probability of the event occurring, is considered not straightforward, and indulgence has a positive relationship.

Power distance has a strong positive link with uncertainty avoidance, long term orientation and a negative link with indulgence. Individualism has a robust negative link with masculinity and long-term orientation. Herein, it is evident that male managers are more long term oriented and that long term orientation means strong uncertainty avoidance. However, indulgence has a negative link with long term orientation.

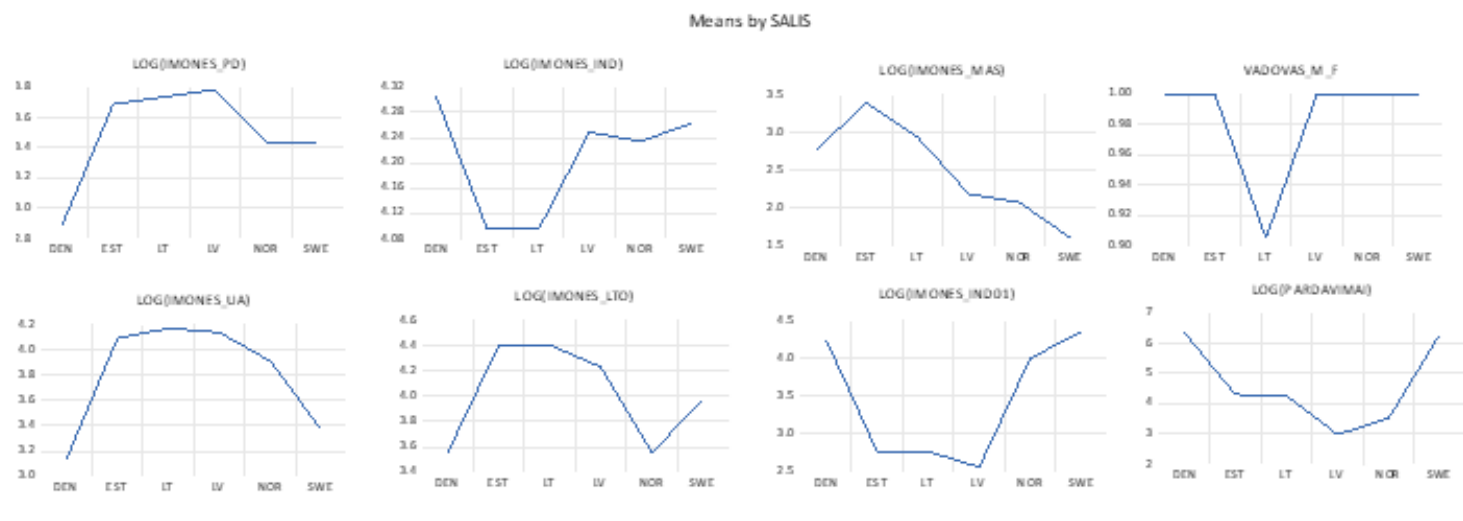

Figure 2. The curves of empiric research in logarithmic values by countries

where: SALIS - Country.

The results presented by countries shows similarities of curves of company revenue with individualism and indulgence.

The authors constructed an equation helping to identify the impact of cultural difference indicators on the company's revenue by following time trends.

\section{Panel equation estimation with GMM method}

The Generalized Moments Method (GMM) is an estimation procedure used in detailed panel data. It allows econometric models to avoid frequently unwanted or unnecessary assumptions, such as the specific distribution of errors. Panel data is a combination of time series and cross-sectional data that contains thousands of observations of companies, each observed at multiple points in time. In addition, the method is generalized. We got the moment estimate by reducing the criterion function by making a sample moment. This research study also covers the application of the GMM method. We provide the equation presenting the impact on company revenue below:

$$
R E V=\beta_{0}+\beta_{1} \text { POWERDIST }+\beta_{2} L T O R+\beta_{3} I N D L G+u_{t}
$$

where REV—logarithmic dependent variable of the company revenue;

$\beta_{0}$-intercept;

POWERDIST - dlog of power distance of the company country;

LOTR - dlog of long-term orientation of the company country;

INDLG - d log of indulgence of the company country;

$u_{t}=$ random model error;

$\beta_{1,2,3}$ - coefficients of elasticity, reflecting the impact of regressors on the revenue of the company.

The constructed equation: 


\section{INSIGHTS INTO REGIONAL DEVELOPMENT}

ISSN 2669-0195 (online) http://jssidoi.org/jesi/

2021 Volume 3 Number 4 (December)

http://doi.org/10.9770/IRD.2021.3.4(7)

$$
R E V=-8.5-3.57 P O W E R D I S T+4.7 \text { LTOR }+1.95 \text { INDLG }
$$

For the construction of the equation, the authors used the residual cross-section dependence test, which results are presented in Appendix B. The results of equation estimation show that power distance has a negative and positive indulgence impact on company revenue. The impact of long-term orientation is specified as a positive impact on company revenue with a probability according to GMM equal to zero. Long-term orientation increases company revenue, the same as indulgence. However, high power distance hurts company revenue increase, and in such cases, better results are obtained only in low power distance countries.

\section{Discussion}

The scientific studies show that context and culture are fundamental for international business operations. By understanding the cultural differences in ethics, beliefs, values, and rules, companies create a diverse corporate and personal culture, which affects the international business results. The authors tried to deliver investigations on the topic, as the study still has much potential. The authors researched all six dimensions of the G. Hofstede approach under the same framework and reached results evaluated by different methods, helping to reach higher clarity on particular interlinks. Specialisation and not power distance demonstration gains the competitive advantage of international business. Long-term orientation helps to correct the company direction and reach future rewards.

Indulgence instrument helps to follow the rigor of the protocols in doing international business. Such three dimensions of culture are leading the company to higher revenue amount and international business expansion. Of course, the research authors used the dimensions of the country's culture where the researched business unit is located. However, other country-based directions are also possible in the future. In addition, the estimations of equations per country could widen the studies. In this paper, the authors investigated only international business units in Scandinavian and Baltic countries. However, the study could be expanded to the revision of framework applications other than this region.

\section{Conclusions}

The literature review results show that there is a lack of studies under the international business that are dedicated to researching cultural dimensions. The authors revised novel concepts of cultural dimensions and selected the G. Hofstede approach. Following the literature review, the authors identified that most authors focus on individualism and the least of authors - on indulgence. Under the empirical study, the authors were dedicated to revising cultural differences' impact on international business revenue. They selected several methods for revision. First, the authors constructed a matrix, which showed that cultural dimensions, except long-term orientation, impact revenues. Then the authors selected equation estimation with the GMM method, which avoids unwanted or unnecessary assumptions and reaches the precise impact of long-term orientation to revenue. After taking corrective actions, long-term orientation has a positive impact on company revenue. Indulgence also has a positive and power distance has - negative impact. This method proves the impact of power distance and indulgence and figures out the impact of long-term orientation. Of course, the cultural dimensions are changing. However, the results are static and do not present the impact of other factors, such as globalisation effect on the change of cultural dimensions. Because of that, they recommended it to repeat the study once in a decade. 
INSIGHTS INTO REGIONAL DEVELOPMENT

ISSN 2669-0195 (online) http://jssidoi.org/jesi/

2021 Volume 3 Number 4 (December)

http://doi.org/10.9770/IRD.2021.3.4(7)

\section{Appendix A}

Dimensions of cultural differences (Hofstede, 1980 \& 2011)

\begin{tabular}{|c|c|c|}
\hline Dimension & Definition & Country \\
\hline Power distance & $\begin{array}{l}\text { The level of acceptance defines the power } \\
\text { distance. The term 'institutions' refers to key } \\
\text { elements of society, such as family, school, } \\
\text { community, and the term 'organization' refers } \\
\text { to different jobs. The high index shows the } \\
\text { hierarchy is clearly defined and unchallenged. } \\
\text { Low index shows the members of the } \\
\text { company or institution have more equal } \\
\text { power. At short distances, decision-making } \\
\text { often requires additional members to justify, } \\
\text { and hierarchies are not formally structured or } \\
\text { completely eliminated. }\end{array}$ & $\begin{array}{c}\text { Low power distance: Belgium Ireland Austria Bulgaria Czech } \\
\text { Republic Denmark Estonia Greece Spain Italy Croatia Latvia Poland } \\
\text { Lithuania Malta Portugal France Romania } \\
\text { High power distance: Slovenia Finland Sweden Hungary Germany } \\
\text { Australia Brazil Canada Chile China Hong Kong India Indonesia Iraq } \\
\text { Japan South Korea Malaysia Mexico Norway Philippines Nigeria } \\
\text { Russia Saudi Arabia Singapore South Africa Republic Switzerland } \\
\text { Thailand Turkey United Kingdom United States Vietnam }\end{array}$ \\
\hline $\begin{array}{c}\text { Individualism } \\
\text { vs } \\
\text { Collectivism }\end{array}$ & $\begin{array}{l}\text { Individualism marks societies in which the } \\
\text { ties between individuals are not strong and } \\
\text { everyone should take care of themselves. } \\
\text { Society's position in this respect is shown in } \\
\text { whether people's image is defined as "I" or } \\
\text { "we". } \\
\text { Collectivism values personal interdependence. } \\
\text { Maintaining social harmony, consensus with } \\
\text { others. }\end{array}$ & $\begin{array}{c}\text { Individualism: Chile, China Hong Kong India Indonesia Iran Iraq } \\
\text { Japan South Korea Malaysia Mexico Norway Philippines Nigeria } \\
\text { Russia Saudi Arabia Singapore South Africa Republic Switzerland } \\
\text { Thailand Turkey United Kingdom United States of Vietnam } \\
\text { Collectivism: Belgium Austria Bulgaria Czech Republic Denmark } \\
\text { Estonia Greece Spain Italy Croatia Latvia Poland Lithuania Malta } \\
\text { Portugal France Romania Slovenia Finland Sweden Hungary Germany } \\
\text { Australia Brazil Canada }\end{array}$ \\
\hline
\end{tabular}

Masculinity: Chile China Hong Kong India Indonesia Iran Iraq Japan

It measures how culture values its gender

Masculinity

vs

Femininity parent, and women's cultures reduce these roles. Men's cultures: they view men as hard conquerors and women as gentle stay-at-home gender differences.

South Korea Malaysia Norway Philippines Nigeria Russia Saudi Arabia

Singapore South Africa Republic Switzerland Thailand Turkey United Kingdom United States Vietnam

Femininity: Belgium Ireland Austria Bulgaria Czech Republic Denmark Estonia Greece Spain Italy Croatia Latvia Poland Lithuania Malta Portugal France Romania Slovenia Finland Sweden Hungary Germany Australia Brazil Canada

Avoiding uncertainty: France Romania Slovenia Finland Sweden Hungary Germany Australia Brazil Chile China Hong Kong India

Avoiding uncertainty will affect (in) tolerance of ambiguities and/or trust in opponents who Avoiding uncertainty vs show unfamiliar behavior, as well as the need Uncertainty tolerant

for structure and ritual in negotiated procedures. Uncertainty tolerant.

ndonesia Iraq Japan South Korea Malaysia Norway Philippines Nigeria

Russia Saudi Arabia Singapore South Africa Republic Switzerland

Turkey Thailand United Kingdom United States Vietnam

Uncertainty tolerant: Belgium Ireland Austria Bulgaria Czech
Republic Denmark Estonia Greece Spain Italy Croatia Latvia Poland Lithuania Malta Portugal

Long-term orientation: Canada Chile China HONG KONG India Indonesia Iran Iraq Japan South Korea Malaysia Mexico Norway

Philippines Nigeria Russia Saudi Arabia Singapore South Africa

Long-term orientation - fostering virtues focused on future rewards, especially perseverance and economy. Short-term Long-term orientation vs orientation means fostering virtues related to Short-term orientation

the past and present, especially respect for traditions, preserving the "face" and fulfilling social obligations.

Republic Switzerland Thailand Turkey United Kingdom United States Vietnam.

Short-term orientation: Belgium Ireland Austria Bulgaria Czech Republic Denmark Estonia Greece Spain Italy Croatia Latvia Poland Lithuania Malta Portugal France Romania Slovenia Finland Sweden Hungary Germany Australia Brazil

Indulgence: Belgium Austria Bulgaria Czech Republic Denmark Estonia Greece Spain Italy Croatia Latvia Poland Lithuania Malta Portugal France Romania Slovenia Finland Sweden Hungary Germany Australia Brazil Canada Chile China Hong Kong.

Restraint: India Indonesia Iran Iraq Japan South Korea Malaysia Mexico Norway Philippines Nigeria Russia Saudi Arabia Singapore South Africa Switzerland Thailand Turkey United Kingdom United States of America Vietnam 
INSIGHTS INTO REGIONAL DEVELOPMENT

ISSN 2669-0195 (online) http://jssidoi.org/jesi/

2021 Volume 3 Number 4 (December)

http://doi.org/10.9770/IRD.2021.3.4(7)

\section{Appendix B}

\begin{tabular}{|c|c|c|c|}
\hline \multicolumn{4}{|c|}{ Residual Cross-Section Dependence Test } \\
\hline \multicolumn{4}{|c|}{$\begin{array}{l}\text { Null hypothesis: No cross-section dependence (correlation) in } \\
\text { residuals }\end{array}$} \\
\hline \multicolumn{4}{|c|}{ Equation: EQ02_GMM } \\
\hline \multicolumn{4}{|l|}{ Periods included: 10} \\
\hline \multicolumn{4}{|c|}{ Cross-sections included: 56} \\
\hline \multicolumn{4}{|c|}{ Total panel (unbalanced) observations: 529} \\
\hline \multicolumn{4}{|c|}{ Note: non-zero cross-section means detected in data } \\
\hline \multicolumn{4}{|c|}{ Test employs centered correlations computed from pairwise samples } \\
\hline Test & Statistic & d.f. & Prob. \\
\hline Breusch-Pagan LM & 4333,175 & 1540 & 0 \\
\hline Pesaran scaled LM & 50,32952 & & 0 \\
\hline Pesaran CD & 10,22791 & & 0 \\
\hline
\end{tabular}

\section{References}

Agodzo, D. (2014). Six Approaches to Understanding National Cultures : Hofstede's Cultural Dimensions. Running Head: Six Approaches to Understanding National Cultures, November, 0-11. https://doi.org/10.13140/RG.2.1.5041.8009

Caputo, Andrea; Ayoko, Oluremi B.; Amoo, Nii; Menke, C. (2019). 1 The relationship between cultural values, cultural intelligence and negotiation styles Pre-print version accepted for publication in the Journal of Business Research Andrea Caputo (. Journal of Business Research, 1-35. https://core.ac.uk/download/pdf/189230807.pdf\%0A

Centre, L. I. (2017). The importance of cultural differences in international business. 1(No.2), 151-170.

Daňková, A., \& Droppa, M. (2015). The Impact of National Culture on Working Style of Slovak Managers. Procedia Economics and Finance, 34(15), 164-171. https://doi.org/10.1016/s2212-5671(15)01615-9

Decker, J. C. (2019). Relationship Between Cultural Distance and Entry Mode by Western European Multinational Enterprises into Eastern Asia Submitted by Jacob Curt Decker A Dissertation Presented in Partial Fulfillment of the Requirements for the Degree Doctorate of Business A. GRAND CANYON UNIVERSITY.

Fan, Z., Huang, S., \& Alexander, W. R. J. (2017). Do national cultural traits affect comparative advantage in cultural goods? Sustainability (Switzerland), 9(7), 1-16. https://doi.org/10.3390/su9071153

Fengfan, M. (2015). Managing Cultural Differences in International Business Negotiations. Proceedings of the 12Th International Conference on Innovation And, 175-179.

Ferreira, M. P., Leiria, I. P. De, \& Li, D. (2007). Is the 'International Business Environment' the Actual Context for IB Research ? University of Texas at Dallas, USA. Management.

Ferreira, P. M. das N. (2017). Negotiation for the middle east: a comparative study of cultures and the construction of a negotiation framework for portuguese in Kuwait. https://repositorio.iscteiul.pt/bitstream/10071/15806/1/pedro_neves_ferreira_diss_mestrado.pdf

Fischer, R., Vauclair, C. M., Fontaine, J. R. J., \& Schwartz, S. H. (2010). Are individual-level and country-level value structures different? testing hofstede's legacy with the schwartz value survey. Journal of Cross-Cultural Psychology, 41(2), 135-151. https://doi.org/10.1177/0022022109354377

Głodowska, A., Pera, B., \& Wach, K. (2016). The International Environment and Its Influence on the Entrepreneurial Internationalization 


\section{INSIGHTS INTO REGIONAL DEVELOPMENT}

ISSN 2669-0195 (online) http://jssidoi.org/jesi/

2021 Volume 3 Number 4 (December)

http://doi.org/10.9770/IRD.2021.3.4(7)

of Firms: The Case of Polish Businesses. Problemy Zarzadzania, 14(3 (62)), 107-130. https://doi.org/10.7172/1644-9584.62.7

Gonzalez, N. L. (2021). ScholarWorks @ GVSU The Impact of Culture on Business Negotiations The Impact of Culture on Business Negotiations. Honors Projects. 839, 13. https://scholarworks.gvsu.edu/honorsprojects/839

Gujrati, R. (2017). Role of environment in International business. International Journal of Advanced Research and Development, 2(November 2017), 53-56.

Guo, Q., Liu, Z., Li, X., \& Qiao, X. (2018). Indulgence and long term orientation influence prosocial behavior at national level. Frontiers in Psychology, 9(SEP), 1-10. https://doi.org/10.3389/fpsyg.2018.01798

Hofstede, G., Hofstede, G. J., Minkov, M. (2010). Culture and Organizations. In International Studies of Management \& Organization (Vol. 10, Issue 4). https://doi.org/10.1080/00208825.1980.11656300

Hofstede, G. (1980). Culture's Consequences International Differences in Work-Related Values (ABRIDGED E). SAGE Publications, Inc. SAGE Publications, Inc

Hofstede, G. (2011). Dimensionalizing Cultures: The Hofstede Model in Context. Online Readings in Psychology \& Culture, 2, 1-26.

Hofstede, G. (2021). Cultural compass. https://www.hofstede-insights.com/product/compare-countries/

Hofstede, G. J., Jonker, C. M., \& Verwaart, T. (2008a). Long-term orientation in trade. Lecture Notes in Economics and Mathematical Systems, 614(January 2008), 107-119. https://doi.org/10.1007/978-3-540-70556-7_9

Hofstede, G. J., Jonker, C. M., \& Verwaart, T. (2008b). Modeling culture in trade: Uncertainty avoidance. Proceedings of the 2008 Spring Simulation Multiconference, SpringSim'08, January, 143-150. https://doi.org/10.1145/1400549.1400567

Hofstede, G. J., Jonker, C. M., Verwaart, T., \& Yorke-Smith, N. (2019). The Lemon Car Game Across Cultures: Evidence of Relational Rationality. Group Decision and Negotiation, 28(5), 849-877. https://doi.org/10.1007/s10726-019-09630-9

Ladhari, R., \& Skandrani, H. (2014). Effects of Individualism and Power Distance on Business Student Judgments of Various Negotiating Tactics. Journal of International Management Studies, 14(1), 103-117. https://doi.org/10.18374/jims-14-1.13

Lanigan, R. L. (1978). : Beyond Culture. Edward T. Hall. American Anthropologist, 80(2), 403-403. https://doi.org/10.1525/aa.1978.80.2.02a00330

Lee, K.-H., \& Herold, D. M. (2016). Cultural relevance in corporate sustainability management: a comparison between Korea and Japan. Asian Journal of Sustainability and Social Responsibility, 1(1), 1-21. https://doi.org/10.1186/s41180-016-0003-2

Lin, C. (2007). Factors affecting innovation in logistics technologies for logistics service providers in China. Journal of Technology Management in China, 2(1), 22-37. https://doi.org/10.1108/17468770710723604

Liu, M. (2019). How Power Distance Interacts with Culture and Status to Explain Intra- and Intercultural Negotiation Behaviors: A Multilevel Analysis. Negotiation and Conflict Management Research, 12(3), 192-212. https://doi.org/10.1111/ncmr.12140

Liu, M., Zhu, L., \& Cionea, I. A. (2019). What Makes Some Intercultural Negotiations More Difficult Than Others? Power Distance and Culture-Role Combinations. Communication Research, 46(4), 555-574. https://doi.org/10.1177/0093650216631096

Liu, W., \& Liu, L. A. (2011). Cultural Intelligence in International Business Negotiation. SSRN Electronic Journal, May 2006. https://doi.org/10.2139/ssrn.905460

Manrai, L. A., \& Manrai, A. K. (2010). The influence of culture in international business negotiations: A new conceptual framework and managerial implications. Journal of Transnational Management, 15(1), 69-100. https://doi.org/10.1080/15475770903584607

Masuda, T., Ito, K., Lee, J., Suzuki, S., Yasuda, Y., \& Akutsu, S. (2020). Culture and Business: How Can Cultural Psychologists Contribute to Research on Behaviors in the Marketplace and Workplace? Frontiers in Psychology, 11(July), 1-20. https://doi.org/10.3389/fpsyg.2020.01304

Merkin, R. S. (2004). Cultural Long Term Orientation and Facework Strategies. Atlantic Journal of Communication, 12(3), $164-176$. https://doi.org/ 10.1207/s15456889ajc1203_3

Minh, H. (2015). the Impacts of Individualism/Collectivism on Consumer Decision-Making Styles: The case of Finnish and Vietnamese mobile phone buyers. 67. https://www.theseus.fi/bitstream/handle/10024/103353/TUAS-Bachelor-Thesis-2015_-HoangMinh.pdf?sequence=1\&isAllowed=y

Mockaitis, A. I., Rose, E. L., \& Zettinig, P. (2012). The power of individual cultural values in global virtual teams. International Journal of Cross Cultural Management, 12(2), 193-210. https://doi.org/10.1177/1470595812439868

Nasdaq.com. (2021). No Title. https://www.nasdaq.com/market-activity/stocks

$\mathrm{Ng}$, S., \& Lim, X. (2019). Are Hofstede's and Schwartz's values frameworks equally predictive across contexts? Review of Business Management, 21(1), 33-47. https://doi.org/10.7819/rbgn.v0i0.3956

Ogihara, Y. (2018). The Rise in Individualism in Japan: Temporal Changes in Family Structure, 1947-2015. Journal of Cross-Cultural Psychology, 49(8), 1219-1226. https://doi.org/10.1177/0022022118781504

Ralston, D. A., Egri, C. P., Furrer, O., Kuo, M. H., Li, Y., Wangenheim, F., Dabic, M., Naoumova, I., Shimizu, K., de la Garza Carranza, M. T., Fu, P. P., Potocan, V. V., Pekerti, A., Lenartowicz, T., Srinivasan, N., Casado, T., Rossi, A. M., Szabo, E., Butt, A., ... Weber, M. (2014). Societal-Level Versus Individual-Level Predictions of Ethical Behavior: A 48-Society Study of Collectivism and Individualism. Journal of Business Ethics, 122(2), 283-306. https://doi.org/10.1007/s10551-013-1744-9

Safiah, Omar, Syukurriah, Idrus, N. (2011). Individualism-Collectivism and Its Influence on Positive Organizational Behavior: An Exploratory Study. American Scientific Publishers, Vol. 4,(2011), 400-407.

Sitharam, S., \& Hoque, M. (2016). Factors affecting the performance of small and medium enterprises in KwaZulu-Natal, South Africa. Problems and Perspectives in Management, 14(2). https://doi.org/10.21511/ppm.14(2-2).2016.03

Vilaplana, Alejandra, GENTNER, A., Favart, \& Carole. (2019). The Role of Communication Tools in the Early-phase Design Process. 
INSIGHTS INTO REGIONAL DEVELOPMENT

ISSN 2669-0195 (online) http://jssidoi.org/jesi/

2021 Volume 3 Number 4 (December)

http://doi.org/10.9770/IRD.2021.3.4(7)

International Journal of Affective Engineering, 18(2), 77-83. https://doi.org/10.5057/ijae.ijae-d-18-00014

Waistell, J. (2011). Individualism and collectivism in business school pedagogy: A research agenda for internationalising the home management student. Higher Education Research and Development, 30(5), 595-607. https://doi.org/10.1080/07294360.2011.598450

Wang, H., Han, X., \& Li, J. (2021). Supervisor Narcissism and Employee Performance: A Moderated Mediation Model of Affective Organizational Commitment and Power Distance Orientation. Basic and Applied Social Psychology, 43(1), 14-29. https://doi.org/10.1080/01973533.2020.1810042

Warter, I., Alexandru, U., Cuza, I., Warter, L., Alexandru, U., \& Cuza, I. (2015). Intercultural Negotiation in Mergers and Acquisitions. the Integration of the Cultural Dimension Into the Negotiation Domain. July, 74-86. https://www.researchgate.net/publication/277919151

Witte, E. H., Stanciu, A., \& Boehnke, K. (2020). A New Empirical Approach to Intercultural Comparisons of Value Preferences Based on Schwartz's Theory. Frontiers in Psychology, 11(July), 1-18. https://doi.org/10.3389/fpsyg.2020.01723

$\mathrm{Xu}, \mathrm{S} .$, \& Hao, A. (2021). Understanding the impact of national culture on firms' benefit-seeking behaviors in international B2B relationships: A conceptual model and research propositions. Journal of Business Research, 130(February), $27-37$. https://doi.org/10.1016/j.jbusres.2021.02.062

Yehia, Y. (2018). The Importance of Cultural Intelligence in International Business. Global Edge, 1-3. https://globaledge.msu.edu/blog/post/55562/the-importance-of-cultural-intelligence

\section{Acknowledgements}

The research was partly supported by The program of internationalization of scientific research of KUL no. W.106.I.2019 (Paths of cooperation - support for entities implementing international cooperation), funded by European Social Fund

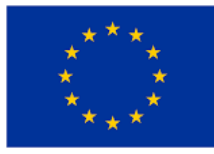

\section{European Union}

European

Social Fund

Edita LEONAVIČIENE் is the is PhD student and lecturer at VILNIUS TECH, Department of Business Technology and Entrepreneurship ORCID ID: $\underline{\text { https://orcid.org/0000-0001-6413-2051 }}$

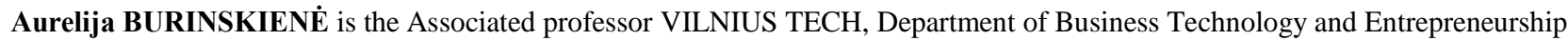
ORCID ID: $\underline{\text { https://orcid.org/0000-0002-4369-8870 }}$

Make your research more visible, join the Twitter account of INSIGHTS INTO REGIONAL DEVELOPMENT: @ IntoInsights

Copyright (C) 2021 by author(s) and VsI Entrepreneurship and Sustainability Center

This work is licensed under the Creative Commons Attribution International License (CC BY).

http://creativecommons.org/licenses/by/4.0/

(c) (i) Open Access 